\title{
CHEMICAL COMPOSITION AND PHARMACOLOGICAL EVALUATION OF ESSENTIAL OIL FROM JASMINUM OFFICINALE FLOWERS FOR SPASMOLYTIC AND VASODILATOR ACTIVITIES
}

\author{
HAFIZ MAJID RASHEED ${ }^{1}$, FAZLI WAHID ${ }^{2}$, RAHILA QAYYUM ${ }^{1}$, ABDUL JABBAR SHAH $^{1}$, \\ TAOUS KHAN ${ }^{1 *}$ \\ ${ }^{1}$ Department of Pharmacy, COMSATS University Islamabad, Abbottabad Campus-22060, Pakistan \\ ${ }^{2}$ Department of Biomedical Sciences, Pak-Austria Fachhochschule: Institute of Applied Sciences and Technology, Mang, \\ Khanpur Road, Haripur, Pakistan
}

*corresponding author: taouskhan@cuiatd.edu.pk

Manuscript received: February 2019

\begin{abstract}
The current study was undertaken to investigate the Jasminum officinale essential oil (Jo. Eoil) for its composition through gas chromatography - mass spectrometry (GC-MS) and pharmacological effects on rabbit jejunum and aorta. Antispasmodic activity was performed on isolated rabbit jejunum while the vasorelaxant effect was studied on rabbit aortic rings using Powerlab data acquisition system. GC-MS analysis indicated 15 constituents in Jo. Eoil. In isolated rabbit jejunum, Jo. Eoil exhibited relaxant effect against spontaneous and high concentration $\mathrm{K}^{+}(80 \mathrm{mM})$-induced contractions with respective median effective concentration of $1.58 \mathrm{mg} / \mathrm{mL}(1.0-2.16)$ and $1.18 \mathrm{mg} / \mathrm{mL}(1-1.36)$, suggesting $\mathrm{Ca}^{++}$channel blockade (CCB) effect. This CCB activity of Jo. Eoil was authenticated by the pre-treatment of the jejunal tissue with Jo. Eoil in calcium free medium, which induced a shift towards right in the concentration response curves for calcium in a similar fashion to verapamil. In isolated aortic rings, cumulative addition of Jo. Eoil caused vascular relaxation against $\mathrm{K}^{+}(80 \mathrm{mM})$ and phenylephrine (PE) induced vasocontractions, with respective median effective concentration of $5.39 \mathrm{mg} / \mathrm{mL}(5.00-5.78)$ and 7.04 (5.00 - 9.08), similar to verapamil. The current study provides a scientific rationale to folkloric uses of J. officinale in gastric and possibly cardiovascular conditions.
\end{abstract}

\section{Rezumat}

Scopul acestui studiu a fost determinarea compoziției uleiului esențial provenit din Jasminum officinale (Jo. Eoil) prin GCMS și investigarea activității antispasmodice asupra jejunului și a activității vasorelaxante asupra inelelor aortice izolate de la iepure. În jejunul de iepure izolat, uleiul de iasomie a prezentat efect relaxant asupra contracțiilor spontane și induse, ceea ce sugerează blocarea canalelor de $\mathrm{Ca}^{++}(\mathrm{CCB})$. Această activitate a uleiului de iasomie a fost demonstrată prin pretratarea țesutului jejunal cu ulei esențial de iasomie în mediu lipsit de calciu, care a imprimat o deplasare spre dreapta în curbele de răspuns ale concentrației calciului, în mod similar cu verapamilul. În inelele aortice izolate, adăugarea uleiului esențial a provocat relaxarea vasculară asupra vasocontracțiilor induse de $\mathrm{K}^{+}(80 \mathrm{mM})$ și fenilefrină $(\mathrm{PE})$, cu concentrația efectivă medie de 5,39 mg/mL $(5,00$ - 5,78) și 7,04 $(5,00$ - 9,08), similară cu cea a verapamilului.

Keywords: Jasminum officinale, essential oil, spasmolytic, vasorelaxation

\section{Introduction}

Gastrointestinal diseases (gastric spasms) have a high incidence rate in the world. Likewise, cardiovascular disorders (hypertension) are the major cause of mortality worldwide. Several studies have shown that there is a link between gastric and cardiac disorders because they exhibit similar symptoms and risk factors [5]. Plants derived natural products from fennel, chamomile, melissa, caraway and peppermint have been traditionally used as antispasmodic and vasorelaxant agents [3]. Essential oils have been reported as a remedy for the treatment of various diseases including inflammation, hypertension [12], gastric spasms [13], oxidative complaints, microbial infections, respiratory disorders and cancer [4].
J. officinale (Oleaceae family) is an attractive vine. It contains sweet smelling flowers that yield fragrant oil [2]. Jasmine oil has wide range applications in traditional medicine including gastric spasms [1] and cardiovascular diseases [14]. Flowering buds of jasmine are used for the treatment of abscess, ulcers, dermatological and ophthalmic disorders. J. officinale is a remedy for hepatitis and duodenitis [21]. It is also used to treat fever, diabetes, diarrhoea, ring worm, ulcers and eruptions in mouth [21].

J. officinale var. grandiflorum contains alkaloids, triterpenoids, flavonoids, tannins, steroids, glycosides, terpenes, salicylic acid and resins. Various components including benzyl alcohol, benzyldehyde, citral, linalool, 2-phenyl ethyl acetate, geraniol, citrinyl acetate, farnesol, eugenol, nerol, geranyl acetate, nerayl acetate, phenyl 
ethyl alcohol and citronellol have been reported to be present in the jasmine essential oil [20].

Biological activities like anxiety, antiviral, cytotoxic, wound healing, genotoxic, allelopathic and cytogenetic [6] of jasmine have been reported in literature. However, no scientific studies have been reported regarding the beneficial effects of $J$. officinale in gut and cardiovascular disorders although it finds application in traditional medicine for the treatment of these diseases. On the basis of above mentioned folkloric uses and other scientific information, it was hypothesized that $J$. officinale may have spasmolytic and vasodilator effects. Therefore, current study was carried out to assess the potential of $J$. officinale essential oil as an alternative treatment for gastrointestinal and cardiovascular disorders. The results provided the evidences that $J$. officinale essential oil might have beneficial effects on gastrointestinal and cardiovascular diseases.

\section{Materials and Methods}

Selection, collection and identification of plant material Jasminum officinale var. grandiflorum Linn. was selected on its folkloric use. The fresh flowers of $J$. officinale were collected from Islamia College Peshawar. The plant specimen was confirmed by Prof. Dr. Shazia Anjum, Director Cholistan Institute of Desert Studies (CIDS), the Islamia University of Bahawalpur, Pakistan. The voucher specimen (3517/CIDS/IUB) was placed in the herbarium of the mentioned institute. Chemicals and standard drugs

Verapamil hydrochloride, phenylephrine, acetylcholine perchlorate, magnesium chloride, potassium chloride, EDTA (ethylenediaminetetraacetic acid) and DMSO (dimethyl sulphoxide) were obtained from Sigma Chemicals Company, St Louis, MO, USA. Chloroform was purchased from Lab-Scan Company Ltd. Bangkok, Thailand. Diethyl ether was purchased from Reanal Fine chemicals Co. Hungary. Calcium chloride, glucose, magnesium sulphate, potassium dihydrogen phosphate, sodium bicarbonate, sodium dihydrogen phosphate, sodium chloride and sodium sulphate were acquired from Merck (Merck, Darmstadt, Germany). Stock solutions of all the chemicals were made in distilled water and dilutions were made fresh on the day of experiment.

\section{Preparation and analysis of essential oil}

Steam distillation, a more common method was used to obtain essential oil from the selected plant. For this purpose, steam was produced using a steam generator and passed to the still containing fresh flowers of $J$. officinale via glass pipe. The vapours were generated from the fresh material (flowers) and collected in the receiver (hydrodistillate). The hydrodistillate was added with diethyl ether and the resultant mixture was positioned in a separating funnel to settle down the aqueous layer. Water contents were removed from the organic layer by treating with sodium sulphate (a desiccant). At low temperature, solvent was evaporated from organic film to get essential oil in pure form. It was kept in an amber colour and well closed glass container and stored at $4-8^{\circ} \mathrm{C}$ for further use. The essential oil was dissolved in DMSO for the pharmacological activities.

The essential oil of $J$. officinale (Jo. Eoil) was investigated for its chemical composition using gas chromatography-mass spectrometry (GC-MS) technique [12]. The GC was performed on Elite-5 MS, Clarus-600 model (PerkinElmer Company, USA) having column with internal diameter $(\mu \mathrm{m})$ of 250 and a length of $30 \mathrm{~m}$. Starting temperature for GC was $50^{\circ} \mathrm{C}$, which was increased up to $300^{\circ} \mathrm{C}$ (end temperature) at an increment of $10^{\circ} \mathrm{C} / \mathrm{min}$ [19]. The sample of essential oil was applied at $1 \mathrm{~mL} / \mathrm{min}$ rate and the injection port temperature was $250^{\circ} \mathrm{C}$. Helium was used as a mobile phase. The mass spectrum (mass scan range; 0 - $450 \mathrm{amu}$ ) was obtained at $70 \mathrm{eV}$. The fragmentation pattern obtained for the identified compounds of the essential oil was compared with NIST Library [15].

\section{Animals}

Locally breed adult rabbits of both sexes $(1-1.5 \mathrm{~kg})$ were used. Animals were provided tap water and standard food freely. The animals were kept abstained from food for $24 \mathrm{~h}$ prior to the experiment. Approved protocols (Research Ethics Committee) from the Department of Pharmacy, COMSATS University Islamabad, Abbottabad Campus, Pakistan, were adopted for animal care. The protocols were in compliance with National Research Council recommendations.

\section{Rabbit jejunum}

Spasmolytic activity of Jo. Eoil was carried out using rabbit jejunal preparations [12]. About $2-3 \mathrm{~cm}$ jejunal tissue was mounted onto the tissue bath in Tyrode solution $(10 \mathrm{~mL})$ with continuous supply of carbogen. Preload (1 g) was given to the tissues. Acetylcholine (Ach) in submaximal dose was used to attain control response. Under these experimental conditions, the jejunal preparations produced spontaneous contractions. Jo. Eoil (cumulative doses) effect was calculated as a percent of control responses produced prior to the test sample addition.

\section{Calcium channel blocking activity}

In order to determine the probable mechanism of Jo. Eoil for spasmolytic effect, tissues were depolarized with high-K $\mathrm{K}^{+}(80 \mathrm{mM})$. After plateau formation, Jo. Eoil was applied in increasing dose to the tissues and $\mathrm{Ca}^{++}$channel blockade (CCB) effect was measured as a percent of effect produced by high concentration $\mathrm{K}^{+}$(control). CCB effect of Jo. Eoil was further authenticated by the procedure mentioned earlier $[9$, 12]. Upon equilibration of tissue, the normal Tyrode's solution was exchanged with calcium free Tyrode solution having ethylenediaminetetra-acetic acid ( 0.1 $\mathrm{mM})$. Later, this solution was also substituted with potassium rich solution. As tissue was stabilized, 
control curves were obtained. Usually, after two cycles, these curves overlap after which Jo. Eoil doses were given in an increasing order. The changes in curves produced by essential oil were compared with control curves to find out the CCB effect.

Rabbit aorta

Vasorelaxant activity of Jo. Eoil was carried out using rabbit aortic rings $(2-3 \mathrm{~mm})$ [9]. The aorta preparations were mounted in tissue bath having Krebs's solution $(10 \mathrm{~mL})$, which was continuously aerated with continuous supply of carbogen. Preload $(2 \mathrm{~g})$ was given to the tissues and kept uninterrupted for $1 \mathrm{~h}$ to equilibrate prior to the application of essential oil. $\mathrm{PE}$ and $\mathrm{K}^{+}(80 \mathrm{mM})$ solutions were added to the tissues for the development of contractions [9]. The Jo. Eoil was given in cumulative doses to examine the vasorelaxant effect of Jo. Eoil.
Statistical analysis

The data given in this study are stated as the \pm standard error of means (SEM). Median effective concentration $\left(\mathrm{EC}_{50}\right)$ values were calculated with $95 \%$ confidence interval $(\mathrm{CI})$.

\section{Results and Discussion}

\section{$G C-M S$ analysis of the essential oil}

GC-MS analysis of $J$. officinale essential oil (Jo. Eoil) obtained through steam distillation process indicated the presence of various constituents (Figure 1, Table I) including 2-propanol, 1-propoxy-, benzyl alcohol, methyl dihydro jasmonate, hydroperoxide pentyl, 3-Butyn-2-ol, 1-pentene, 1-pentanol, isobutylene epoxide, Cis-2-hexene, 3-butanoic acid ethyl ester, 3methyl glutaric anhydride, Cis-4-heptenal, 2-butenol, 2-methyl beta-butyrolactone and 5-hexene-2-one.

Table I

Identified components (GC-MS) of essential oil obtained from Jasminum officinale by the process of steam

\begin{tabular}{clcccc}
\hline S. No. & \multicolumn{1}{c}{ Component } & Ret. Time (min) & Mol. Wt. & Mol. Formula & Peak Area \\
\hline 1 & Isobutylene epoxide & 2.62 & 72 & $\mathrm{C}_{4} \mathrm{H}_{8} \mathrm{O}$ & 174009 \\
2 & 2-Propanol, 1-Propoxy- & 3.04 & 118 & $\mathrm{C}_{6} \mathrm{H}_{14} \mathrm{O}_{2}$ & 2291986 \\
3 & 5-hexene-2-one & 3.39 & 98 & $\mathrm{C}_{6} \mathrm{H}_{10} \mathrm{O}$ & 406194 \\
4 & Hydroperoxide pentyl & 3.5 & 104 & $\mathrm{C}_{5} \mathrm{H}_{12} \mathrm{O}_{2}$ & 2436924 \\
5 & Beta-Butyrolactone & 3.59 & 86 & $\mathrm{C}_{4} \mathrm{H}_{6} \mathrm{O}_{2}$ & 622013 \\
6 & Methyl dihydro jasmonate & 3.62 & 226 & $\mathrm{C}_{13} \mathrm{H}_{22} \mathrm{O}_{3}$ & 18118 \\
7 & 2-butenol 2-methyl & 3.69 & 84 & $\mathrm{C}_{5} \mathrm{H}_{8} \mathrm{O}$ & 673288 \\
8 & 3-butanoic acid ethyl ester & 4.08 & 114 & $\mathrm{C}_{6} \mathrm{H}_{10} \mathrm{O}_{2}$ & 345785 \\
9 & 3-Butyn-2-ol & 5.25 & 70 & $\mathrm{C}_{4} \mathrm{H}_{6} \mathrm{O}$ & 74092 \\
10 & Benzyl alcohol & 7.3 & 108 & $\mathrm{C}_{7} \mathrm{H}_{8} \mathrm{O}$ & 6001 \\
11 & Cis-4-Heptenal & 7.39 & 112 & $\mathrm{C}_{7} \mathrm{H}_{12} \mathrm{O}$ & 276383 \\
12 & 1-Pentene & 7.4 & 70 & $\mathrm{C}_{5} \mathrm{H}_{10}$ & 27491 \\
13 & 3-methyl glutaric anhydride & 7.88 & 128 & $\mathrm{C}_{6} \mathrm{H}_{8} \mathrm{O}_{3}$ & 147072 \\
14 & Cis-2-Hexene & 8.46 & 84 & $\mathrm{C}_{6} \mathrm{H}_{12}$ & 85979 \\
15 & 1-Pentanol & 9.61 & 88 & $\mathrm{C}_{5} \mathrm{H}_{12} \mathrm{O}$ & 135272 \\
\hline
\end{tabular}

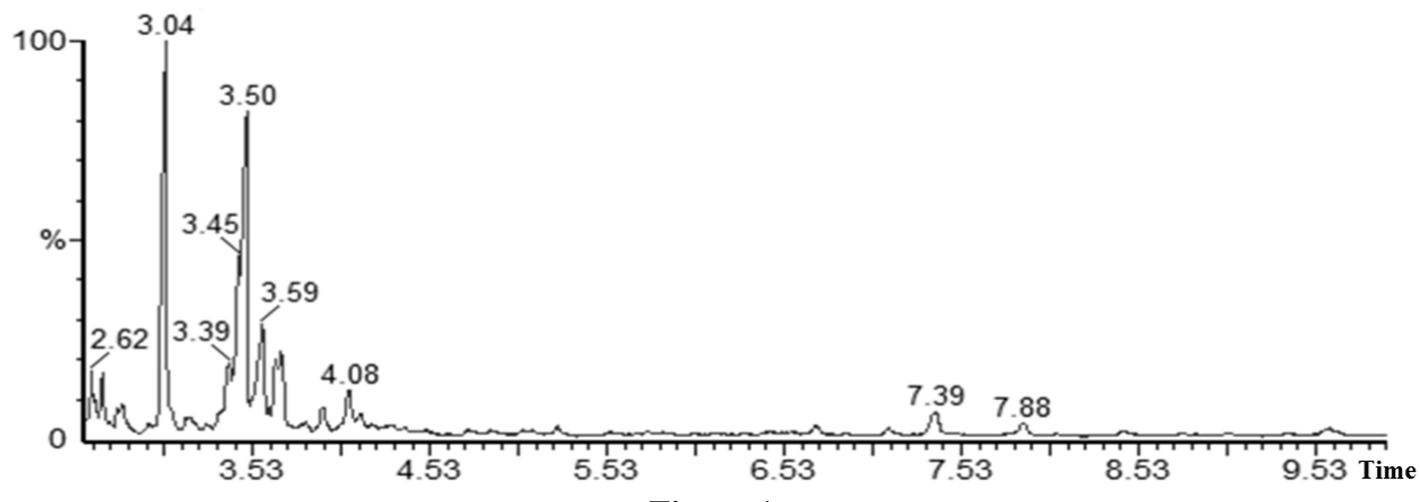

Figure 1.

Gas chromatograph of J. officinale essential oil obtained through process of steam distillation

Among the identified compounds, benzyl alcohol has been reported in J. officinale and J. sambac [20] and methyl dihydro jasmonate in Jo. Eoil [14]. The other compounds identified in Jo. Eoil have not been previously reported in $J$. officinale or related species. However, some peaks remained unidentified.
Spasmolytic activity of the essential oil Isolated jejunum was used to determine the spasmolytic activity of Jo. Eoil $(0.01-5 \mathrm{mg} / \mathrm{mL})$. The tissue was totally relaxed at $5 \mathrm{mg} / \mathrm{mL}$ (Figure 2A). Jo. Eoil blocked the spontaneous and high- $\mathrm{K}^{+}$-induced contractions with $\mathrm{EC}_{50}$ values of $1.58 \mathrm{mg} / \mathrm{mL}(1.0-2.16)$ and 
$1.18 \mathrm{mg} / \mathrm{mL}$ (1.0 - 1.36), respectively (Figure 3A). The spasmolytic effect of Jo. Eoil showed similar pattern to verapamil (standard calcium channel blocker) (Figure 2B). Respective $\mathrm{EC}_{50}$ values of verapamil against spontaneous and high- $\mathrm{K}^{+}(80 \mathrm{mM})$ induced contractions were $0.06 \mathrm{mg} / \mathrm{mL}(0.03-0.09)$ and $0.02 \mathrm{mg} / \mathrm{mL}(0.01-0.04)$ (Figure 3B).
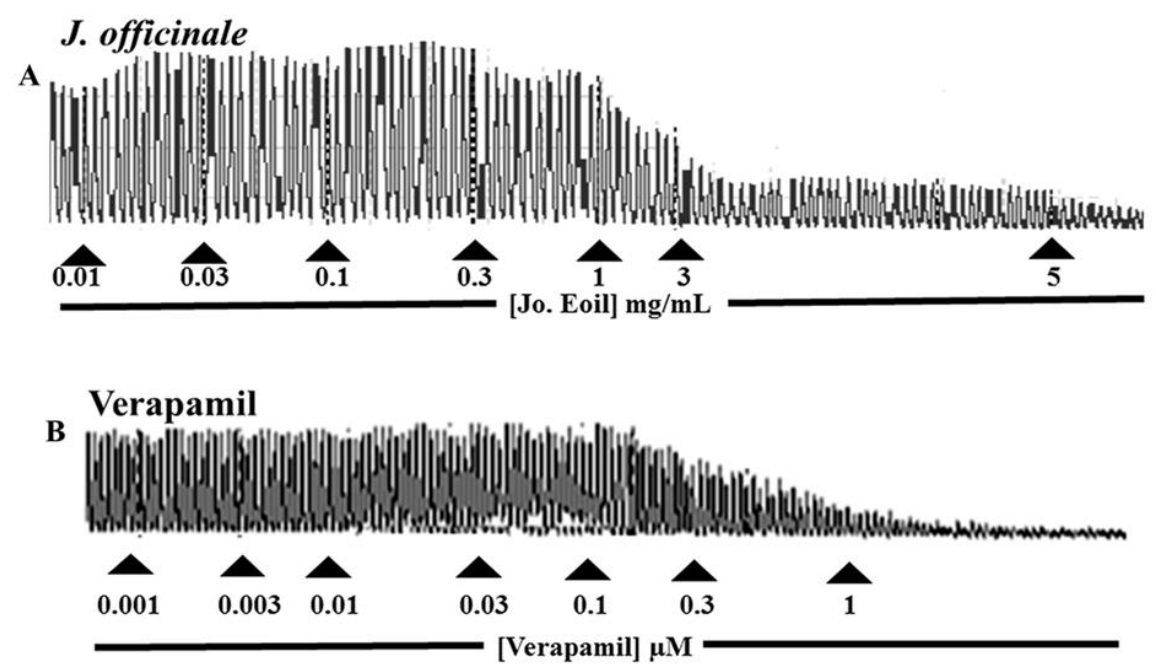

Figure 2.

Typical tracing showing the concentration-dependent spasmolytic effect of (A) J. officinale essential oil and (B) verapamil on spontaneously contracting isolated rabbit jejunum preparations. Where, $\mathrm{X}$-axis $=$ concentration of sample and $\mathrm{Y}$-axis = spasmolytic response
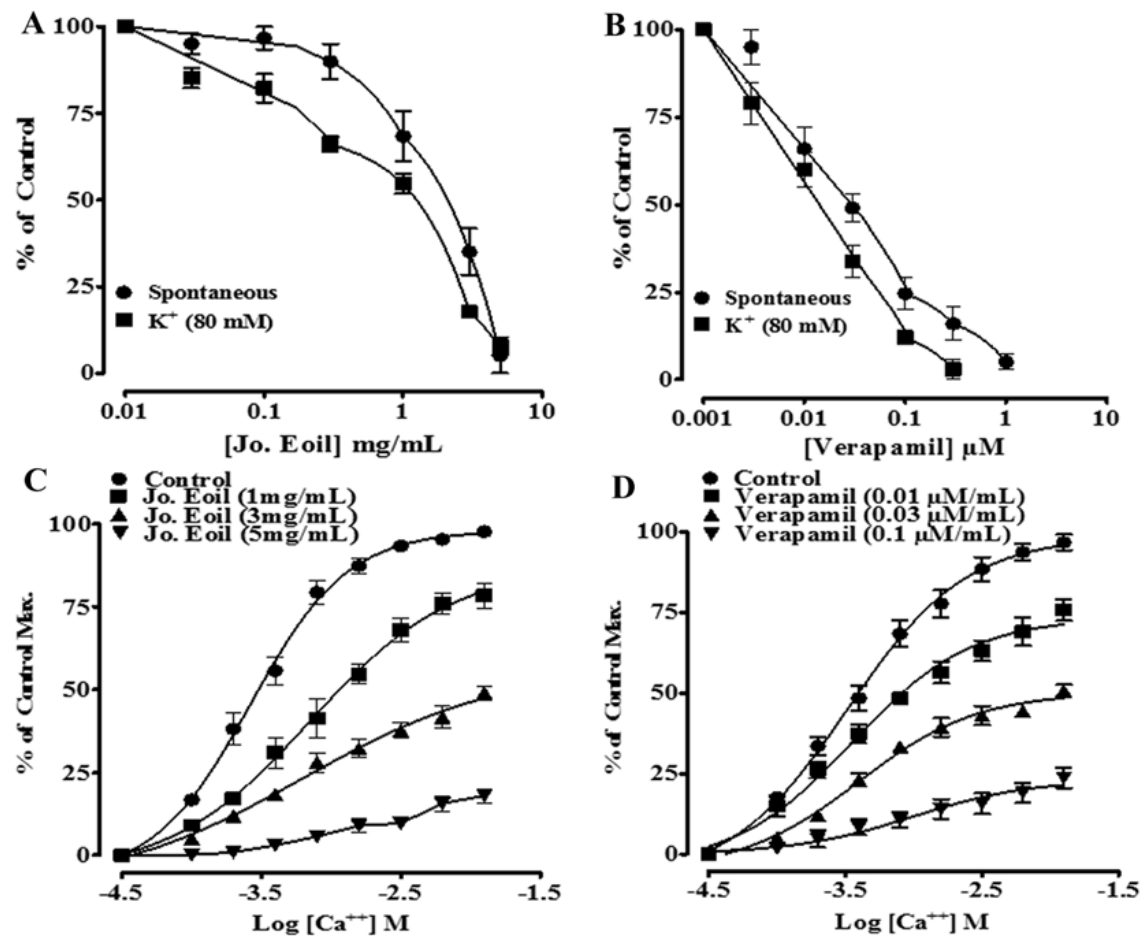

Figure 3.

Graphical representation of concentration-dependent spasmolytic effect of (A) J. officinale essential oil and (B) verapamil on spontaneously and $\mathrm{K}^{+}(80 \mathrm{mM})$ induced contractions in isolated rabbit jejunum preparations.

Figure 3C and $\mathbf{D}$ shows relaxing effect of $J$. officinale essential oil and verapamil on $\mathrm{Ca}^{++}$concentrationresponse curve in isolated rabbit jejunum preparations, in $\mathrm{Ca}^{++}$free medium. Values shown are mean $\pm \mathrm{SEM}(n=3)$

This effect was further validated when pretreatment of the jejunal preparations with cumulative addition of Jo. Eoil (1-5 mg/mL) produced shift in the calcium concentration curve towards right (Figure 3C) similar to verapamil (0.03-0.3 $\mu \mathrm{M})$ (Figure 3D), suggesting the involvement of $\mathrm{Ca}^{++}$entry blocking effect. It has 
been reported that high $\mathrm{K}^{+}$opens voltage dependent $\mathrm{Ca}^{++}$channels (VDCs) [7], which results in the influx of calcium that produces contraction of the tissues [7, 16]. The inhibitory effect of Jo. Eoil against high $\mathrm{K}^{+}$induced contractions suggests that it mediates effect by inhibiting $\mathrm{Ca}^{++}$influx through VDCs. In previous studies, we have reported the spasmolytic effect of essential oil on rabbit jejunum in dose dependent manner at the concentration of 1 $\mathrm{mg} / \mathrm{mL}$ and $3 \mathrm{mg} / \mathrm{mL}$ for Rosa indica and Psidium guajava, respectively $[12,13]$. In this study, results showed that Jo. Eoil has comparable efficacy with the reported spasmolytic effect of other plant essential oils. This provides pharmacological basis for the medicinal use of $J$. officinale essential oil as anti- spasmodic and antidiarrheal agent. The CCBs are reported to be useful in smooth muscle spasms and diarrhoea [8]. On this basis, we can conclude that $J$. officinale essential oil might be used as an alternative option for synthetic CCBs.

Vasorelaxant activity of the essential oil

Jo. Eoil $(0.01-10 \mathrm{mg} / \mathrm{mL})$ was tested for vasorelaxant activity against the vasoconstrictions induced by high- $\mathrm{K}^{+}(80 \mathrm{mM})$ and phenylephrine $(\mathrm{PE})$ using in vitro aorta preparations. Maximum effect was observed at $10 \mathrm{mg} / \mathrm{mL}$ against both high- $\mathrm{K}^{+}$and $\mathrm{PE}$ induced contractions (Figure $4 \mathrm{~A}$ and $4 \mathrm{~B}$ ) with $\mathrm{EC}_{50}$ values of $5.39 \mathrm{mg} / \mathrm{mL}(5.0$ - 5.78) and 7.04 (5.0 9.08), respectively (Figure 4C).

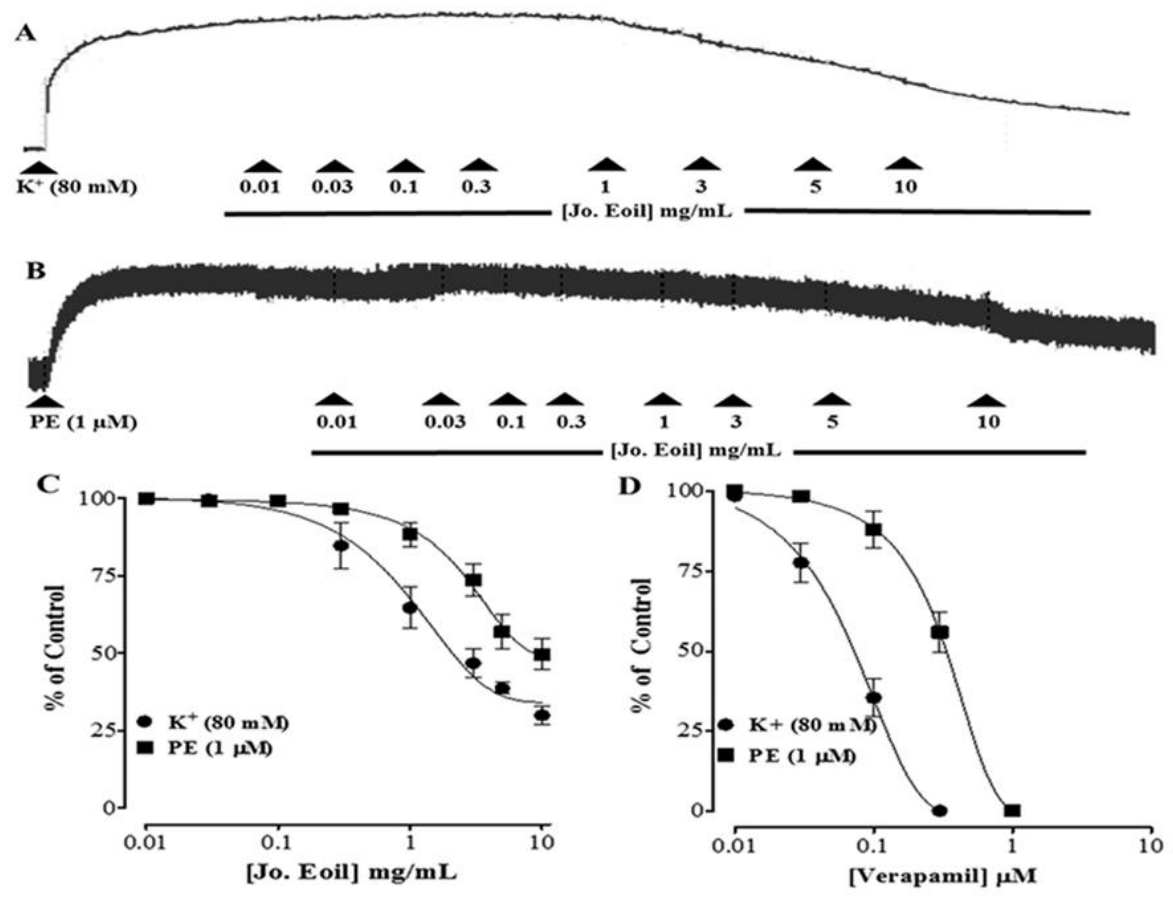

Figure 4.

Representative tracings showing the vasorelaxant effect of $J$. officinale essential oil on $(\mathbf{A}) \mathrm{K}^{+}(80 \mathrm{mM})$ and $(\mathbf{B})$ phenylephrine (PE)-induced contractions in isolated rabbit aorta preparations. Figure $\mathbf{C}$-D, show concentration-

response curve of $J$. officinale essential oil and verapamil on $\mathrm{K}^{+}(80 \mathrm{mM})$ and phenylephrine (PE)-induced

vasoconstrictions in isolated rabbit aorta preparations. Values shown are mean $\pm \operatorname{SEM}(n=3)$

$\mathrm{EC}_{50}$ values for vasorelaxant effect of verapamil were $0.04 \mu \mathrm{M}(0.03-0.05)$ and $0.51 \mu \mathrm{M}(0.03-0.73)$ against high $\mathrm{K}^{+}$and $\mathrm{PE}$-induced contractions, respectively (Figure 4D). It has been reported that essential oil from Pogostemon elsholtzioides presented dose-dependent vasodilation in pre-contracted aortic rings and PEinduced vasocontractions at the concentration of 1 $\mathrm{mg} / \mathrm{mL}$ [18]. Our research group has previously reported $[12,13]$ the vasodilatory potential of essential oil from $R$. indica and $P$. guajava on rabbit aortic rings in a dose dependent manner $(0.01-10 \mathrm{mg} / \mathrm{mL})$ and maximum effect was observed at the concentration of $10 \mathrm{mg} / \mathrm{mL}$ which is comparable to the current study. Interestingly, in aortic rings, Jo. Eoil exhibited a partial vasorelaxant effect against $\mathrm{PE}$ and high $\mathrm{K}^{+}$precontractions (equipotent). However, verapamil, a typical $\mathrm{Ca}^{++}$entry blocker [7] caused complete relaxation of $\mathrm{PE}$ and high $\mathrm{K}^{+}$pre-contractions. It also shows that the $\mathrm{Ca}^{++}$entry blocking constituents are more effective in the gastrointestinal preparation than vascular, which is in line with heterogenous nature of $\mathrm{Ca}^{++}$ entry blockers [10] and support the importance of $J$. officinale more in gastrointestinal than the cardiovascular disorders.

\section{Conclusions}

The data indicated the presence of several constituents in the essential oil of $J$. officinale. The $J$. officinale 
essential oil also provides the scientific basis for the remedies of gastrointestinal (gut spasm and diarrhoea) and cardiovascular (hypertension) disorders. So, the $J$. officinale essential oil might be used as the replacement of calcium channel blockers (CCBs) as it showed CCB like mechanism. However, more detailed chemical analysis and molecular mechanisms of $J$. officinale essential oil are suggested in future studies.

\section{Conflict of interest}

The authors declare no conflict of interest.

\section{References}

1. Arun M, Satish S, Anima P, Phytopharmacological profile of Jasminum grandiflorum Linn. (Oleaceae). Chin J Integr Med., 2016; 22: 311-320.

2. Bhattacharya $S$, Bhattacharya $S$, In vitro propagation of Jasminum officinale L.: a woody ornamental vine yielding aromatic oil from flowers. Methods Mol Biol., 2010; 589: 117-126.

3. Catap ES, Kho MJL, Jimenez MRR, In vivo nonspecific immunomodulatory and antispasmodic effects of common purslane (Portulaca oleracea Linn.) leaf extracts in ICR mice. J Ethnopharmacol., 2018; 215: 191-198.

4. de Andrade TU, Brasil GA, Endringer DC, da Nóbrega FR, de Sousa DP, Cardiovascular activity of the chemical constituents of essential oils. Molecules, 2017; 22: 1-18

5. Gesualdo M, Scicchitano P, Carbonara S, Ricci G, Principi M, Ierardi E, Di Leo A, Cortese F, Ciccone MM, The association between cardiac and gastrointestinal disorders: causal or casual link?. J Cardiovasc Med., 2016; 17: 330-338.

6. Ghurde MU, Deshmukh VR, Pulate PV, Malode SN, Cytotoxic and genotoxic potential assessment of leaf extract of Jasminum officinale L. var. grandiflorum L. Int J Innov Biosci., 2012; 2: 112-117.

7. Gilani AH, Shah AJ, Ghayur MN, Majeed K, Pharmacological basis for the use of turmeric in gastrointestinal and respiratory disorders. Life Sci., 2005; 76: 3089-3105.

8. Godfraind T, Miller R, Wibo M, Calcium antagonism and calcium entry blockade. Pharmacol Rev., 1986; 38: 321-416.

9. Janbaz KH, Nisa M, Saqib F, Imran I, Zia-Ul-Haq M, De Feo V, Bronchodilator, vasodilator and spasmolytic activities of methanolic extract of Myrtus communis L. J Physiol Pharmacol., 2013; 64: 479-484.

10. Koike K, Taka yanagi I, Takiguchi S, Urita Y, Miyake $\mathrm{N}, \mathrm{Ca}^{++}$-blocking action of stereoisomers of CI-
951, (+)-CI-951, (NC)-1500 and (-)-CI-951 in the isolated muscle preparations. Gen Pharmacol., 1992; 23: 207-210.

11. Lv Y, Yang F, Li X, Zhang X, Abbas S, Formation of heat-resistant nanocapsules of jasmine essential oil via gelatin/gum arabic based complex coacervation. Food Hydrocoll., 2014; 35: 305-314.

12. Rasheed HM, Khan T, Wahid F, Khan R, Shah AJ, Chemical composition, vasorelaxant and antispasmodic effects of essential oil from Rosa indica L. petals. Evid Based Complem Altern Med., 2015; 2015: 1-9.

13. Rasheed HM, Khan T, Wahid F, Khan R, Shah AJ, Chemical composition and vascular and intestinal smooth muscle relaxant effects of the essential oil from Psidium guajava L. fruit. Pharm Biol., 2016; 54: 2679-2684.

14. Sandeep PM, Jasminum grandiflorum Linn (Chameli): ethnobotany, phytochemistry and pharmacology A review. Pharmacologyonline, 2009; 2: 586-595.

15. Satyal P, Paudel P, Lamichhane B, Setzer WN, Volatile constituents and biological activities of the leaf essential oil of Jasminum mesnyi growing in Nepal. J Chem Pharm Res., 2012; 4: 437-439.

16. Shah AJ, Gilani AH, Abbas K, Rasheed M, Ahmed A, Ahmad VU, Studies on the chemical composition and possible mechanisms underlying the antispasmodic and bronchodilatory activities of the essential oil of Artemisia maritime L. Arch Pharm Res., 2011; 34: 1227-1238.

17. Shah AJ, Gilani AH, Blood pressure-lowering and vascular modulator effects of Acorus calamus extract are mediated through multiple pathways. $J$ Cardiovasc Pharmacol., 2009; 54: 38-46.

18. Shiva KA, Jeyaprakash K, Chellappan DR, Murugan $\mathrm{R}$, Vasorelaxant and cardiovascular properties of the essential oil of Pogostemon elsholtzioides. J Ethnopharmacol., 2017; 199: 86-90.

19. Siddique AB, Rahman SMM, Hossain A, Chemical composition of essential oil by different extraction methods and fatty acid analysis of the leaves of Stevia rebaudiana Bertoni. Arabian J Chem., 2016; 9: S1185-S1189.

20. Younis A, Mehdi A, Riaz A, Supercritical carbon dioxide extraction and gas chromatography analysis of Jasminum sambac essential oil. Pak J Bot., 2011; 43: 163-168.

21. Zhao G, Yin Z, Dong J, Antiviral efficacy against hepatitis $b$ virus replication of oleuropein isolated from Jasminum officinale L. var. grandiflorum. $J$ Ethnopharmacol., 2009; 125: 265-268. 